\title{
Early Childhood Social and Emotional Development of Suku Anak Dalam (SAD)
}

\author{
Zakiyah $^{1, *}$, Nurhafizah $^{2}$ \\ 1,2 Universitas Negri Padang \\ *Corresponding author. Email: zakiyaaira1083@gmail.com.
}

\begin{abstract}
The purpose of this study was to determine the social and emotional development of tribal children in the Nurul Ikhlas Play Group, Bukit Suban Village, Air Hitam District, Sarolangun Regency. The research used a qualitative approach. The results shows that 1) the early childhood learning process of the Nurul Ikhlas Play Group of the Suku Anak Dalam had used a standard curriculum for early childhood education, 2) social and emotional learning was conducted slowly by repetition, and storytelling, 3) in general the social abilities of Suku Anak Dalam children include the ability to get along, socialize and communicate well with friends and teachers, work together, be patient when waiting for their turns, take care and help friends, share food and toys, compromise with friends and be responsible.
\end{abstract}

Keywords: Social development, emotional development, Suku Anak Dalam.

\section{INTRODUCTION}

From an early age a child must be brave and able to face the differences in this social life. According to Muhibbin [1], social development is a process of forming a social self, namely individuals in the family, culture, nation, and so on. Social life skills as part of life skills are the basic assets for interaction. The ability to work together with understanding, empathy, and the ability to communicate in two directions are part of social life skills that are needed by someone in building a harmonious relationship.

Children from an early age are required to have social life skills so that they can coexist with other people and the environment. Coaching efforts from birth to 6 years of age to assist physical and spiritual growth and development so that children have readiness to enter further education [2]. This is also in accordance with the Mayar's opinion [3] that the development of children's social behavior is marked by an interest in the activities of friends and an increase in a strong desire to be accepted as a member of a group, and dissatisfied when not with their friends. Social skills are not formed suddenly, but are imitation and habituation of the child's closest environment.

Broadly speaking, emotional social development includes social and emotional development. The purpose of children's social development is to help and make it easier for children to start socializing with people around the child, namely parents, teachers, siblings and peers and to help children get along with the new environment [4]. Meanwhile, the ability of children to manage their own emotions is part of the maturation of children's emotions during the transitional period from pre-operational to the concrete operational period. The ability of early childhood to manage their own emotions can be seen from the dimensions of the child's ability to use their own emotions positively, the ability to regulate emotions according to their own situation and condition, and the ability to defend themselves in various forms of children's self-problem positions naturally [5].

From the above opinion it can be concluded that social and emotional development in early childhood is very important to be developed because the child's ability to manage emotions and interact socially with other people is needed when children enter the environment around them. Without the ability to manage emotions and the ability to have good social interactions, children will find it difficult to adapt to their social environment. This ability will also help children to find their identity and role in real life. According to Im GW [6] explaining that social and emotional competence has been established as important predictors of children's mental health, school readiness and academic success.

Aspects of Social Skills According to Gottman and Declare in Susanto [7] there are social benefits for children, namely, 1) Children have a friendly attitude and are easy to get along with their peers, 2) Children 
have tolerance and concern for others, 3) Have an attitude social interests (happy to help others), 4) The child has a happy attitude to share and cooperate, 5) The child has a democratic attitude in socializing, 6) The child is able to communicate well with others, 7) The child is able to resolve conflicts with other people, 8) Children have the understanding and ability to analyze relationships with others.

According to Gerungan [8] that the acquisition of children's social and emotional learning experiences is certainly different, the social emotional development of early childhood can be formed from the experiences of children in the environment where the child lives. Hence the emotions of young children appear different from those of older children or adults. Agree with Aqib [9] characteristics of children's emotions are strong emotions, often visible emotions, temporary emotions, and children's emotions can be identified through children's behaviour.

According to Faisal [10] the characteristics of children who are emotionally well developed are that they have patience, are able to hold back and control themselves, can adapt, take initiative, are creative, care, independent, responsible, like friendly, able to communicate, and influence people. others, have dreams, are optimistic, persistent, resilient, like challenges, and are confident. From this opinion, it can be concluded that everyone has a different pattern of social and emotional development, especially in our country, Indonesia, which has a variety of ethnicity, religions, languages and habits, which form the unity of the Indonesian nation.

According to Ibrahim [11] in Sumatra there are a number of large tribes that have traditional characteristics. Famous tribes include Aceh, Batak, Minang Kabau, and Malay. In addition, there are also several minority tribes who inhabit several areas in Sumatra, especially in large forest areas, between large rivers, around swamps, and on offshore islands. One of these minority tribes is the Suku Anak Dalam (SAD) or commonly referred to as the Orang Rimba.

Sager [12], the Kubu tribe or also known as the Suku Anak Dalam (SAD) or the Orang Rimba is a minority ethnic group that lives on the island of Sumatra, to be precise in Jambi and South Sumatra Provinces. Broadly speaking, in Jambi the Suku Anak Dalam (SAD) live in 3 different ecological areas, namely the Orang Kubu in the north of Jambi Province (around the Taman Nasional Bukit 30), the Taman Nasional Bukit 12, and the southern part of Jambi Province (along the Sumatra highway). They live nomadically and depend on hunting and gathering.

Since 1999 the government no longer uses the term isolated community for the Suku Anak Dalam community, but instead uses the term KAT (Komunitas Adat Terpencil/remote indigenous communities) [13]. The government's attention is not only to provide settlements for the Suku Anak Dalam but the government also equip it with educational facilities and infrastructure, for example early childhood education, one of which is the Nurul Ikhlas play-group for the Suku Anak Dalam. Initially, the Suku Anak Dalam PlayGroup did not have a clear direction and purpose, until in 2009 PT Sari Aditya Loka-1 (PT.SAL-1) a group of PT Astra Agro Lestari Tbk made it a target school.

\section{METHOD}

This article is the result of a descriptive study with a qualitative approach. This study aims to describe the social and emotional development of Suku Anak Dalam, especially in early childhood, the Suku Anak Dalam PlayGroup, Nurul Ikhlas, Bukit Suban Village, Air Hitam District, Regency in Sarolangun. Data collection techniques in qualitative research using observation, interview and documentation techniques. In general, according to Miles and Huberman in [14], it is explained that activities in qualitative data analysis start from data collection, data reduction, data presentation and drawing conclusions based on these data. Interview was conducted with Mrs. Fenti Rahmawati as the coordinator of Corporate Social Responsibility (CSR) for Suku Anak Dalam from PT. Sari Aditya Loka.

\section{RESULT AND DISCUSSION}

\subsection{Suku Anak Dalam's Social Skills}

The life of the Suku Anak Dalam has also been explained based on the results of research by Arsa [15] that the activities that are usually carried out by the Suku Anak Dalam (in the age range of 4-6 years), they play on the bank of a tributary not far from genah (settlement). they). They sometimes catch fish or other animals such as turtles and turtles by using the tools available or with their bare hands. For boys under 6 years, they usually accompany their older siblings on a tour of the forest, looking for large frogs or certain plants.

The following is a table of activities in the daily activities of Suku Anak Dalam. 
Table 1. Activities of the daily life of the children of the Suku Anak Dalam

\begin{tabular}{|l|l|l|l|}
\hline No & Gender & Age & Activities \\
\hline 1. & Male & $>13$ year & $\begin{array}{l}\text { a) Joined hunting in the forest during the day with adult men. For example, hunting pigs, } \\
\text { turtles, big frogs. } \\
\text { b) Join in setting up the Snare at night. } \\
\text { c) Join in looking for plants, fruits and food to mix. }\end{array}$ \\
\cline { 2 - 5 } & Female & $>13$ year & $\begin{array}{l}\text { a) There are those who enter the garden looking for oily palms. } \\
\text { b) Helping mothers cook and care for their younger siblings. Sometimes they join mothers in } \\
\text { looking for plants to mix. }\end{array}$ \\
\hline 2. & Male & $\begin{array}{l}7-13 \\
\text { year }\end{array}$ & $\begin{array}{l}\text { a) Playing, taking a walk in the forest around Genah. } \\
\text { b) Learn to catch fish in the river water in the forest. }\end{array}$ \\
\cline { 2 - 5 } & Female & $\begin{array}{l}7-13 \\
\text { year }\end{array}$ & $\begin{array}{l}\text { a) Play to find pets that can be used as pets like toys, such as large frogs, turtles and so on. } \\
\text { Almost the same thing with boys of the same age. } \\
\text { b) Some have helped cook and take care of their younger siblings. }\end{array}$ \\
\hline 3. & Male & $3-6$ year & $\begin{array}{l}\text { a) Playing to find animals that can be used as pets, such as big frogs, turtles and so on. } \\
\text { b) Join an older friend to catch fish in the creek, in the forest. On average, the Tribe Inner } \\
\text { Children (SAD) already have pets such as large frogs or monkey cubs. } \\
\text { c) Follow his parents in the forest to look for Sempayang fruit. }\end{array}$ \\
\cline { 2 - 5 } & Female & $3-6$ year & $\begin{array}{l}\text { Almost the same as boys, already have pets such as big frogs or monkey children, etc. And } \\
\text { also look for fruit Sempayang in the forest. }\end{array}$ \\
\hline
\end{tabular}

Data Source [15].

From the table above, the life of the Suku Anak Dalam is generally almost the same. Forests, rivers, animals, it is a very attractive play area for them, natural life that is already one with nature.

Based on the results of an interview on Monday, November 4, 2019 conducted by the researcher with Mrs. Fenti Rakhmawati as the coordinator of the Corporate Social Responsibility (CSR) for Suku Anak Dalam Education from PT. Sari Aditya Loka. He explained that the behavior of the Suku Anak Dalam which tends to be primitive is caused by environmental factors where they live in the forest so they do not recognize civilization outside the forest. During its development, the Suku Anak Dalam became a serious concern of the Jambi provincial government. Some of the families of the Suku Anak Dalam have been placed in their own settlements around the forest edges of the Bukit Dua Belas National Park. The Suku Anak Dalam is not a defensive tribe who likes to fight to defend its territory. Suku Anak Dalam in the community prefer to stay away and live in shifts from one area to another.

Based on the results of interviews, observations and documentation, it is known that in general the social abilities of early childhood in ethnic groups include the ability to get along, socialize and communicate well with friends and teachers, cooperate, be patient waiting their turn, care and help friends, share food and toys, succumbing to friends and being responsible, seen in the inner tribe of the child, it's just that the level of ability is not like children in general.

\subsection{Suku Anak Dalam's Emotional Ability}

In the interview with Ms. Fenti, she also explained that in the special development aspects of the emotional development of Suku Anak Dalam children, it is very different from children in general. The pattern of the law of the jungle is still inherent in Suku Anak Dalam children, violence and selfishness and wanting to win by themselves are still so strong even though they have made villages and started to mingle with the surrounding community.

Suku Anak Dalam early childhood is a unique child, different from children in general. A free life, roaming the forest without any binding rules. One of the factors causing the pattern of social emotional development that has not developed properly can be motivated by the environment, traditions, habits and from uneducated families, making the early childhood of the Suku Anak Dalam experience lagging in all aspects of development.

This does not make teachers or educators discouraged in educating Suku Anak Dalam children, they do various ways so that Suku Anak Dalam children's education develops well. This is in accordance with the opinion explained by [16] that both parents and teachers are considered as the most important emotional socializers in preparing children with various experiences that develop abilities or hinder. the development of emotional competence itself. The teacher's job is not only to transfer the knowledge, skills and technology they have to their students, but the teacher also has to carry out the tasks that are assigned to him by the community. The tasks intended include 
teaching culture in a broad sense, life skills, and life values [17].

According to Mrs. Fenti Rahmawati's statement, as the coordinator of the Corporate Social Responsibility (CSR) for Suku Anak Dalam Children Education from PT. Sari Aditya Loka from the results of the interview, he also explained that learning for Suku Anak Dalam Children still adheres to the curriculum made by the government plus local content according to the environment around the area. As well as developing aspects of child development, namely religious and moral values, language, cognitive, physical motor, art and social emotional.

\subsection{The Role of Teachers in Developing Social Aspects of Early Childhood in PG Nurul Ikhlas Suku Anak Dalam}

In the daily learning process at the Suku Anak Dalam Play Group in Nurul Ikhlas, Bukit Suban Village, Air Hitam District, Regency Sarolangun. All aspects of child development are always the teacher's attention, one of which is social and emotional development.

From the results of the interview, the researcher with Ibu Susilawati, one of the educators of the Suku Anak Dalam Nurul Ikhlas, who also comes from the Suku Anak Dalam, explained that the social and emotional of early childhood in the Nurul Ikhlas Play Group is indeed far from the lives of children in general. selfishness, often fighting over toys by force, fighting and others. Freedom that they do without being bound by rules. In the application of this children's social and emotional understanding, they cannot follow the standards set by the government, namely Permen 134 of 2014. For Suku Anak Dalam early childhood, this standard is too high. Its application is not age-appropriate, for example for 56 years of age, they use the standard of 4-5 years.

\subsection{Storytelling Methods in Developing the Social and Emotional Ability of Inner Children}

Based on the results of observations and interviews, it is known that the methods and treatment of social and emotional development are carried out repeatedly and slowly. The method most often teachers use in calming children when they show unfavourable or emotional behaviour is by telling stories. Peace began to appear. Explaining the social meaning even by telling stories, citing stories of events that they had never heard before. Such a method is one of the ways that educators or teachers usually develop the social and emotional development of early childhood in the Suku Anak Dalam.
The results are starting to appear, the attitude of willing to share, tolerance, controlling emotions began to appear. The storytelling method used in this education is one way to teach, develop and provide understanding to children about social relationships with friends or other people, as well as placing their emotions naturally even though slowly.

This storytelling method is one of the methods in the social and emotional development of early childhood. In helping the social and emotional development of children, the right approach is needed, this is expressed by Suryana [18], namely through exemplary, which means learning that is displayed through good examples, and using various examples that have been accepted by the community. This approach is important because early childhood is a great copycat and easily absorbs what he sees.

In addition, Gunarti [19] states that storytelling is an activity carried out by someone to convey a message, information or a fairy tale that can be done verbally or in writing. In addition, the storytelling method has many benefits, namely providing a number of social knowledges, moral and religious values. Moeslichatoen [20] mention some of the benefits of the storytelling method, namely as follows: 1) the storytelling method provides a learning experience to practice listening. Through listening to children, they obtain various kinds of information about knowledge, values and attitudes to be lived and applied in everyday life. 2) the storytelling method allows children to develop effective cognitive and psychomotor for each child. 3) the storytelling method is able to provide information about the social life of the child with the people in between with various jobs.

\section{CONCLUSION}

Based on the description above, it can be concluded that the early childhood learning of the Suku Anak Dalam has used the standard early childhood education curriculum plus local content according to local conditions. It's just that the application of the standards used in learning, especially in the Nurul Ikhlas Suku Anak Dalam of Children in Bukit Suban Village, Air Hitam District, Regency. Sarolangun is not yet suitable for early childhood in general, due to several factors, for example from the surrounding environment, freedom without clear rules, parental background, traditions and so on.

The pattern of the law of the jungle is still inherent in the Anak Dalam tribe, violence and selfishness and wanting to be victorious on their own are still so strong even though they have made a village and begin to mingle with the surrounding community. Social and emotional development is done in an iterative, slow manner. The method most often teachers use in calming 
children when they show unfavorable or emotional behavior is by telling stories. Calmness begins to appear. The storytelling method used in this education is one way to teach, develop and give children an understanding of social issues with friends or other people, as well as placing their emotions naturally even though slowly.

Furthermore, considering that there has not been much research done on early age children of ethnic children, especially in terms of the social and emotional development of researchers' expectations, it is very necessary to do research on other aspects because of the importance and urgency of their needs for education and knowledge, as well as government attention and paying attention to children's social life. However, it is not knowledge that destroys or eliminates their traditions and habits, but efforts are also needed to increase the need for education which is of particular concern to all elements of society.

\section{ACKNOWLEDGMENTS}

The author would like to thank all those who have helped the author, especially to Dr. Nurhafizah, M.Pd, who has helped researchers in perfecting the results of this study. Thanks, are also given to the editorial team of Icece 5th who has provided suggestions, criticism and recommendations for improvement.

\section{REFERENCES}

[1] Muhibbin S. Psikologi pendidikan dengan pendekatan baru. Bandung: PT. Remaja Rosda Karya; 2010.

[2] Nurhafizah. Pelatihan pembuatan media pembelajaran anak usia dini menggunakan bahan sisa. 2018;2(2):1-10.

[3] Mayar F. Perkembangan anak usia dini sebagai bibit untuk masa depan bangsa. Jurnal Al-Ta'lim. 2013;6:459-64.

[4] Hurlock E. Perkembangan anak. Jilid 2. Jakarta: Erlangga; 1978.

[5] Mulyana D. Ilmu komunikasi: Suatu pengantar. Bandung: PT. Remaja Rosdakarya; 2014.

[6] Im GW, Jiar YK, Talib RB. Development of preschool social emotional inventory for preschoolers: A preliminary study. International Journal of Evaluation and Research in Education. 2019;8(1):158-64.

[7] Susanto A. Perkembangan anak usia dini. Jakarta: PT. Bumi Aksara; 2017.

[8] Gerungan W. Psikologi sosial. Bandung: PT. Refika Aditama IKAPI; 2004.

[9] Aqib Z. Penelitian tindakan kelas. Bandung: CV. Yrama Widya; 2009.
[10] Faisal A. Menyiapkan anak jadi juara. Jakarta: Elex Media Komputindo; 2013.

[11] Ibrahim M. Kehidupan Suku Anak Dalam di kecamatan Air Hitam kabupaten Sarolangun [Doctoral dissertation, Universitas Pendidikan Indonesia]. Bandung: UPI; 2013.

[12] Sager S. The sky is our roof, the earth our floor: Orang Rimba customs and religion in the Bukit Duabelas region of Jambi, Sumatra. [Doctoral thesis, Australian National University]. Canberra: ANU; 2008

[13] Direktorat Pemberdayaan Komunitas Adat Terpencil Direktorat Jendral Pemberdayaan Sosial Departemen Sosial RI. Pedoman teknis pemberdayaan komunitas adat terpencil. Jakarta; 2003.

[14] Sugiyono. Memahami penelitian kualitatif. Bandung: Alfabeta; 2012.

[15] Arsa D, Atmazaki A, Juita N. Literasi awal pada anak usia dini suku anak dalam Dharmasraya. Jurnal Obsesi: Jurnal Pendidikan Anak Usia Dini. 2019;3(1):127-36.

[16] Denham SA, Bassett HH, Zinsser K. Early childhood teachers as socializers of young children's emotional competence. Early Childhood Education Journal. 2012;40(3):137-43.

[17] Maiza Z, Nurhafizah N. Pengembangan keprofesian berkelanjutan dalam meningkatkan profesionalisme guru pendidikan anak usia dini. Jurnal Obsesi: Jurnal Pendidikan Anak Usia Dini. 2019;3(2):356-65.

18] Suryana D. Pendidikan anak usia dini: Stimulasi \& aspek perkembangan anak. Jakarta: Prenada Media; 2016.

[19] Gunarti W, Suryani L, Muis A. Metode pengembangan perilaku dan kemampuan dasar anak usia dini. Jakarta: Universitas Terbuka; 2008.

[20] Moeslichatoen. Metode pengajaran di Taman Kanak-Kanak. Jakarta: PT. Rineka Cipta; 2004. 